\title{
Community-Oriented Policing: Political, Institutional and Technical Reforms in Khyber Pakhtunkhwa (KP) Police
}

\author{
Bahadar Nawab ${ }^{1 *}$, Shakir Ullah ${ }^{1}$, Ingrid Nyborg ${ }^{2}$, Tahir Maqsood ${ }^{1}$ \\ ${ }^{1}$ COMSATS University Islamabad, Abbottabad, Pakistan \\ ${ }^{2}$ Norwegian University of Life Sciences (NMBU), Ås, Norway \\ *Corresponding author: E-Mail: bahadar@cuiatd.edu.pk; Tel.: +92 992 383491-5; Fax: +92 992383441
}

Submitted: 5 June 2018 | In revised form: 21 May 2019 | Accepted: 29 May 2019 |

Published: 26 July 2019

\begin{abstract}
Community-police relations in Pakistan are often intricate, as are their reforms. Mistrust, political intervention, meager financial resources, lack of educated/trained human resources, over-expectations and miscommunication are some of the factors contributing to weak policing and poor community-police relations. The police as a service-oriented public institution has been a demand of the public and the dream of consecutive governments. In this study, we explore the political, institutional and technical reforms taken by the government of Khyber Pakhtunkhwa (KP) and the police department to improve their police and policing. The Police Act 2017 and Community-Oriented Policing, Dispute Resolution Councils (DRCs), and Information and Communications Technology (ICT) initiatives are critically analyzed in terms of their intentions and contribution to improved police-community relations. Politicians, police, civil society organizations and community members from KP were interviewed for their perceptions of police reforms and community-police relations. The study finds strong political will to empower and depoliticize police, and to shift its focus from purely crime fighting into community service provision, including pro-active engagement of police with the community. The study also finds that most of the new initiatives of the government of $\mathrm{KP}$ are in the spirit of community-oriented policing, and community members see visible improvement in policing and community-police relations.
\end{abstract}

Keywords: Community-oriented policing; police reforms; Khyber Pakhtunkhwa; Pakistan

\section{Introduction}

The post-9/11 wave of militancy and suicide attacks in Pakistan, and in Khyber Pakhtunkhwa (KP) and tribal areas in particular, created widespread fear and insecurity among the public. KP was the worst affected province where terrorism, kidnapping for ransom, target killing, and extortion were common [1]. The police thus face many security challenges which jeopardize both national security and people's civil liberties [2]. The KP police were as well the target of militants and they suffered many casualties [3]. The primary role of police in Pakistan and KP has always been maintaining the law and order situation in order to ensure a peaceful society and internal/domestic security. However, after 9/11 and subsequent extremist militancy, military operations and other insecurities, the roles, responsibilities and challenges of police diversified and became more complicated. The police increased their focus on internal security together with 
the army, who was responsible for border control and overall security of the country. In extreme situations, Rangers (a wing of the Pakistan Army, and the Frontier Constabulary in $\mathrm{KP}$ and Baluchistan) also took the role of police.

Faced with such immense security challenges, the government began a new cycle of police reform. For better coordination and active response to extremism and terrorism the government established National Counter Terrorism Authority (NACTA) in 2009, initially under the Ministry of Interior but later as an autonomous authority answerable to a Board of Governors headed by the Prime Minister of Pakistan. NACTA, headed by senior police officers, acts to unify state response to extremism and terrorism by combining the efforts of law enforcement and intelligence agencies and by formulating and implementing national counter terrorism and counter extremism policies through strategic planning, continuous research and innovation.

At the same time, the National Police Bureau (NPB)has re-established itself as the premier institution for steering police reform efforts at the national level in Pakistan. With their vision of 'Reshaping police into a professionally competent, operationally neutral and publicly accountable service-delivery organization', they provide strategic guidance, policy and competence-building in democratic policing approaches. The police have long been considered one of Pakistan's most ineffectively managed government institutions. They are poorly trained, ill-equipped, politicized, and incessantly corrupt [4]. Pakistan inherited its policing system from Great Britain, the colonial masters in South Asia. The police Act of 1862 was promulgated immediately in the aftermath of the 1857 uprising against British rule [5]. This policing model provided for an oppressive, unaccountable and authoritarian police force. This force was and still is using century-old tactics, which do not meet the requirements of policing in today's Pakistan where citizens expect more democratic government processes [6]. Pakistan followed the 1862 Act until 2002, when a new reform-oriented police order was finally enacted. The 2002 order proposed significant changes in both the structure and culture of the police, with the intention to transform it into a democratic and depoliticized institution. However, the 2002 order's original intent and spirit was damaged due to frequent amendments over time [7]. In the years since the 2002 Act, more than two dozen commissioned reports on police reform were assembled, but it was very rare for any of their recommendations to be implemented [8]. The NPB has renewed reform efforts by providing professional guidance in democratic policing at the national level.

One of the NPB's newest areas of focus, for example, is Community-Oriented Policing (COP). The terms 'community-based policing' and 'community-oriented policing' began to appear in academia during the mid-1960s in the United States, and in the early 1970s in the United Kingdom and Australia. The idea suggests a paradigm shift from the 'exclusion' of society from policing to its 'inclusion', where society is given an explicit role in policing [9].

The concept of community-oriented policing means dif- ferent things to different communities of practice [10]. Nevertheless, community-oriented policing models often have in common the central idea that community members and police are in an active partnership and close coordination, whether this is referred to as problem-solving, problem oriented, or sector policing [11].

This is in stark contrast to earlier understandings of the concept of community policing as a form of community surveillance through informants (which still exists in many contexts, including in Pakistan). Ras [11] argues for the importance of cementing trust between communities and police, and the sharing of information to handle common issues. Community-oriented policing is both a philosophy (a way of thinking) and an organizational strategy (a means to carry out that philosophy) that allows the police and community to work together in new ways to solve problems of crime and disorder, and ensure safety and security. It rests on two core elements: changing the methods and practice of the police and taking steps to establish a relationship between the police and the public [12]. A community-oriented policing approach thus emphasizes both reforming the police and refurbishing their public image [13]. Developing a professional and accountable police service practicing a new style of policing that is responsive to the needs of local communities is increasingly recognized as important for sound conflict management [12]. Community-oriented policing brings together the police, civil society and local communities to jointly take responsibility for and develop solutions to local safety and security [14]. Community-oriented policing theories suggest that citizens, through their social relationships, are key in ensuring a peaceful and law-abiding society, and the police have only a small role to play in this. Eck and Rosenbaum claim that the larger issues of insecurity are in fact social processes underpinned by informal social relations maintained in neighborhoods, rather than police issues [15]. The move towards COP by NPB reflects a broader shift from an exclusive focus on harder security issues, to one of human security, where the police address a broader set of local security concerns which contribute to trust-building and better police-community relations.

The extent to which the NPB is able to influence the implementation of community-oriented policing from their national position, however, may be limited. After the passing of the $18^{\text {th }}$ Amendment in 2010 where most government ministries were devolved to the provinces, each province in Pakistan now has its own police. They work in different historical and cultural contexts, and are governed differently by political governments. Current police reforms at the provincial level have to deal not only with insecurity from terrorism and extremism, but also with demands by the public for more democratic policing institutions. In KP in particular, human insecurity remains high, and trust between the government and the communities, and between community members, remains at a deficit. During crisis periods, police worked closely with the army to fight terrorism, and found little time to interact with the community [16].

Nevertheless, the KP police are focusing on improving 
police-community relations through legal, social and technical means. This paper focuses on recent key political, social and technical reforms in police and policing in KP, and how they, given the insecurity, address the challenges faced by police and build public trust. Specifically, the Police Act 2017 and Community-Oriented Policing, Dispute Resolution Councils (DRCs), and Information and Communications Technology (ICT) initiatives are critically analyzed in terms of their intentions and contribution to improved police-community relations. We examine how these reforms affect both the attitude and efficiency of police, and how the police is trying to build trust with local communities to both fight crimes and ensure human security.

\section{Methodology}

The research was based on a qualitative methodology. Open-ended and semi-structured interviews were held in two police stations: one in district Swat, and one in $\mathrm{Pe}$ shawar. A total of four villages, two under the jurisdiction of each police station, were selected to get the perceptions of the local community about police and community-oriented policing. The criteria for selecting these two police stations was that both stations are equipped with relatively modern and advanced methods of policing where communityoriented policing, DRC and ICTs are practiced. The police stations and villages were selected to ensure representation of gender, minorities, youth and class differences. A total of 20 individual interviews were conducted with key police officials of different ranks including women and men(ten from each police station). In each police station one Focused Group Discussion (FGD) with police officials of different ranks (who are the real face of police in the public) was conducted. Two group interviews with the members of two DRCs in Peshawar and Swat respectively were conducted to understand their dispute resolution processes. In addition, a total of 20 in-depth interviews were conducted in the four villages with selected key community members (women, men, minorities, and youth). One FGD with selected male leaders was conducted in each village to get the overall picture of community-police relationships. In addition, a total of ten local politicians (men and women) were interviewed from the selected villages. Purposive sampling was used to select respondents from both the police stations and the areas under their jurisdiction. Efforts were made to select diverse respondents from the community and politicians, including some who have good or bad experience with police. Socio-economic, ethnic and nature of disputes factors were also considered while selecting respondents. Police officers and others who work in the field with communities were also purposely selected keeping in mind their ranks and track records of work experience. Participant observation and personal observations were used as techniques for data collection throughout the fieldwork. Desk research involved the review of academic articles and other literature related to community policing, DRCs, police acts/orders, policing patterns in Pakistan in general, and $\mathrm{KP}$ in particular.

A question guide was developed for each group of respondents to explore, for example, how different actors perceive security and insecurity, community-police relations, trust-building, and recent police reforms such as the new Police Act, DRCs and ICT-based initiatives.

\section{Findings and Discussion}

In this section, we begin with a brief description of the police structure in KP, including a brief presentation of their training courses, to provide a backdrop for our discussions of police competence and attitudes towards the communities. We then move to examine three key political, social and technical reforms: The Police Act of 2017 and CommunityOriented Policing (COP), the Dispute Resolution Councils (DRCs), and the use of ICTs in the police. In each case we analyze the intent of the reforms, as well as police and community experiences and perceptions of how they have affected trust between the police and communities and contributed to greater human security in the communities.

\subsection{Police Structure in KP}

The police in Pakistan are organized on two levels. Senior police officials are employees of the federal government, but appointed to serve throughout the country in all provinces. Once appointed in a province, they fall under the administrative control of the province and provincial police chief, the Inspector General of Police (IGP). Junior police employees are a provincial workforce under the command and guidance of the senior federal police officers (see Fig. 1). 

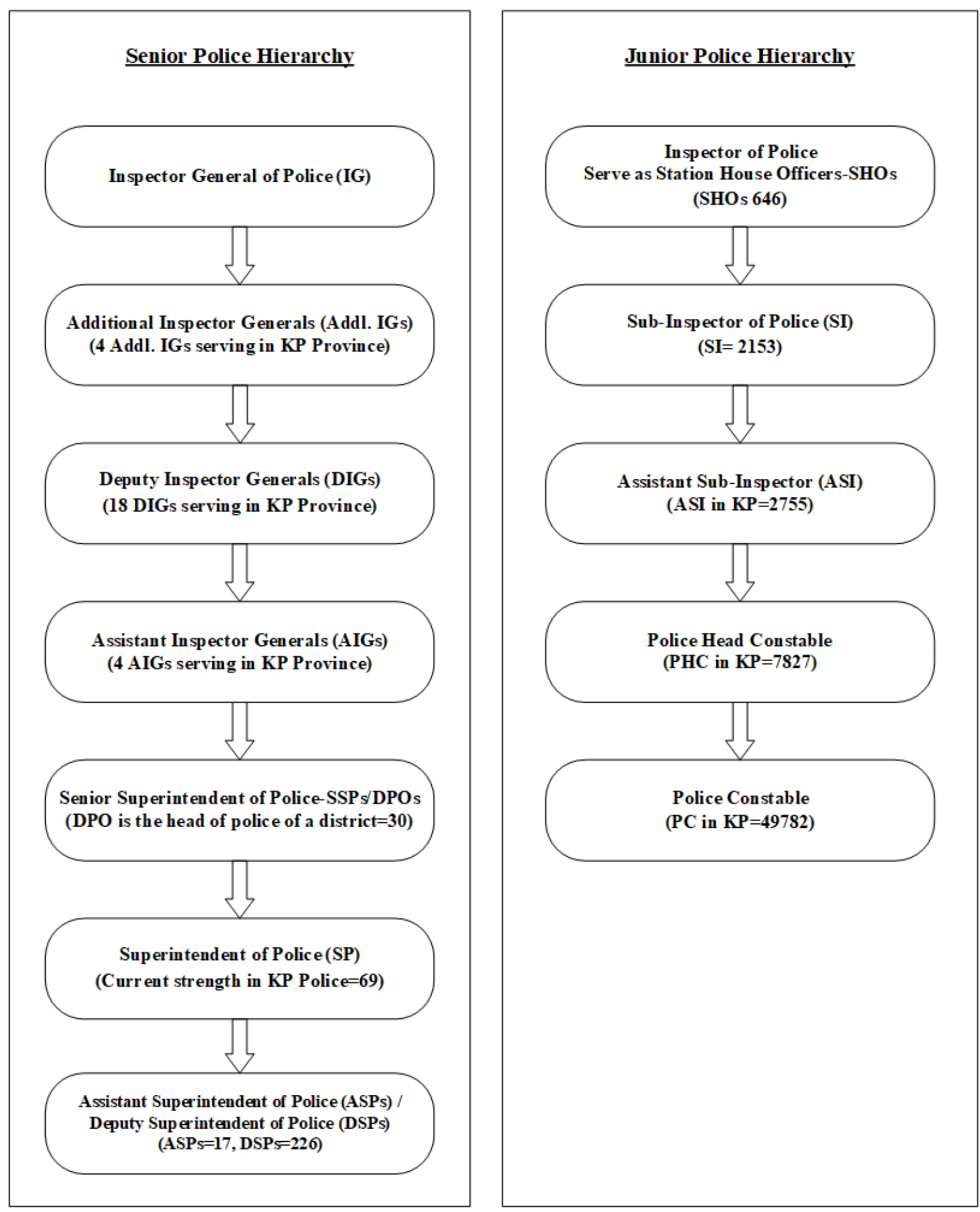

Figure 1. Police Hierarchy in KP

The total police strength in KP is around 63532, which comprises 63163 police personnel and lower rank officials who work at police station level, and 369 police officers coming through competitive selection of the federal government and who control the provincial police department. Since the police officers shown in the higher hierarchy are employees of the federal government, they are frequently transferred and rotated among the provinces. All the trainings of these police officials are organized by the National Police Academy, Islamabad. The Initial Command Course (ICC) is an 18 month Specialized Training Program (STP) designed for the new entrants of Police Service of Pakistan (PSP) or mid-level police managers. This training consists upon four different phases i.e. (a) Foundation; (b) Devel- 
opment; (c) Field Attachment and (d) Consolidation. They also attend refresher courses from time to time. In addition to this, Senior Command Courses (SCCs) are organized for District Police Officers (DPOs) of the country to manage the overwhelming challenges of leadership responsibilities posed by acts of terrorism and major crimes, as well as political, civilian, economic, financial and personnel issues within their ever-changing, diverse environments. The key issues inculcated in the SCCs training include the following:

- Manage Crime

- Oversee and Maintain Law and Order

- Supervise Administration

- Supervise Critical Incident Response

- Manage Security

- Interact with and Mediate Pressure Groups

- Maintain Media Relations

- Collect/Update Intelligence

- Manage Community Policing

The National Police Academy arranges a variety of twoweek Capacity Building Courses (CBCs) on different policing subjects. The broad themes of CBCs training include the following:

- Counter Terrorism and Anti-Terrorism

- Mass Demonstrations and Crowd Control

- Management and Leadership Skills

- Investigation and Criminalities

- Organized Crimes

- Operational Policing

- Modern Approaches in Policing

- Personal Growth, Health and Attitude

- Special Skills in Policing

Community policing is a part of sub-module under the Modern Approaches in Policing and is not in itself considered important enough be an independent module. Specially Designed Courses (SDCs) are also organized for police officers and law enforcement agencies. These courses are arranged on demand, and separate curriculum is developed considering the demand of the department.

For police serving in the lower hierarchy, each province has their own training centers. In KP, two recruiting centers in Swat and Swabi were recently established in addition to the earlier one in Hangu District.To manage new crimes and growing challenges of terrorism and extremism, the police department has also established six training schools. These include: Police School of Investigation (May 2014), Police School of Intelligence (June 2014), Police School of Tactics (July 2014), Police School of Explosive Handling (Feb 2015), Police School of Public Disorder and Riot Management (Jan 2015) and Police School of Information Technology (Sept 2015). These schools have been established to impart specialized training to police personnel in order to effectively counter the emerging challenges posed by the incessant asymmetric warfare. The training in these schools has been linked to promotions, and all the police officers have to undergo various courses being conducted in these schools. The curricula of police recruiting centers and different schools are focused more on crimes, investigation and control of public. Community policing as such is still not part of curricula in these recruiting centers or specialized schools.

\subsection{Political Reforms: KP Police Act of 2017 and COP}

Police as an institution and its role, services and performance is criticized throughout the county, and the police as an independent, well-equipped and well-trained service institution for the community remains a dream. Police officials and analysts blame the 1861 Police Act for this menace, which is inherited from the British colonial era where the focus is on use of force and control over the public. The majority of public respondents, however, have little knowledge of the 1861 Police Act, and just try to avoid contact with police. For them, the police can find clauses and excuses from within their system to complicate situations, creating problems rather than providing service to communities. The worst curse on an enemy in the study area is that 'police may encounter you and you may face a court case'.

Most of the respondents both from police and community agreed that police as an institution has hardly changed over the years. Police still use forceful tactics for spreading fear and anxiety to get control over the public. During consecutive civil and military governments, police often demonstrated themselves as a cruel force. Governments, instead of bringing reforms in police, would use them to suppress their opponents. This resulted in what the public often refers to as 'Thana Culture' (political use of the police force) in Pakistan. It is due to this power, that the police department is still an attractive job in Pakistan. As a result, the community and police stand as foes instead of as partners for peace and security.

The security situation in the context of war in neighboring Afghanistan and the migration of millions of Afghan Refugees to Pakistan after the Soviet invasion of Afghanistan in 1979 have also had an important impact on reinforcing the repressive role of police in Pakistan in general and KP in particular. After 9/11, the security situation in Pakistan worsened. Historically the role of police in Pakistan and KP was to maintain internal law and order situation in the province. In KP, the Frontier Constabulary (FC) is another paramilitary force responsible for maintaining law and order, and controlling criminal gangs. The FC deals with situations out of the capabilities of the regular police force of KP, particularly on the earlier boarder between KP and the tribal areas. Border and external security, on the other hand, was maintained by the Pakistan Army and their attached forces such as Rangers and Frontier Corps. However, a rise in militancy change the security situation in the country and KP. Fighting terrorism and militancy became an additional task for police for which they were not trained. Series of military operations created insecurity, and the inefficiency of police was exposed as they could not provide security to the public since they themselves were targeted.

To counter the growing threats from militants and to maintain peace and security in the country, the government 
has realized that the need for more investment and reforms in the police was urgent. In recent years, all administrative units and provinces in Pakistan have introduced technical and institutional reforms to improve the police. In 2009, the basic pay of the police of all provinces was increased 100 percent, and they were afforded PKR 10000 - 12800 in monthly allowance. Also, training centers have been established in each province to improve police competence.

The KP Police continued to move forward with its own reforms. They devised a diagnostic approach and strategic framework. This strategic framework aimed at winning public trust through better service delivery and transforming the police from reactionary to problem-solving. In 2014, the Chief Minister of the KP province increased the salaries of all police forces in the province by RS 2600 for protecting public life and property and fighting terrorism [17]. In 2018, through official notification[18], the government of KP revised police pay scale of lower rank police men/women like Constable (BPS-05) to (BPS-07); Head Constable (BPS-07) to (BPS-09) and Assistant Sub-Inspector (BPS-09) to (BPS-11). The rise in salary and up-grading of the pay scale has ensured reasonable financial benefits and boosted the morale of police. Policing is now a respected job and they work with more dedication.

The KP government and police have progressed ahead of the rest of the provinces in terms of police legislation by passing KP's Police Act 2017 [19]. This Act seeks reconstruction and regulation of the provincial police with an aim to make it 'apolitical' and 'accountable to civilian oversight' [20]. There are several councils and committees established to contribute to better communication and relations between the police and the public. Chapter 4, Section 47 of the Police Act 2017, for example, emphasizes the establishment of Public Liaison Committees (PLCs), where $70 \%$ of its members are to be selected from the concerned village councils or neighborhood councils, while $30 \%$ of its members will be people of high repute and integrity [19]. These committees are expected to assist the local police in crime prevention and maintenance of public order, and inform the police about local tensions, new people entering the area, or anything else that might disturb the peace. The councils and committee are open for all, but traditionally these forums are dominated by men with little representation of women. In some areas, the police are working with civil society organizations to form women PLCs and to ensure youth are also included. For example, the police in collaboration with UNDP and other civil society organizations introduced PLCs in 10 conflict-affected districts of KP Province. These councils comprise 30 members, and while male youth are participating, women are still underrepresented [21].

Reforms in police, including behavior and attitudinal change in the police department, are the key objectives of the KP government. When asked about the new Police Act, none of our respondents from the selected community had gotten a chance to read it, and many of them had not even heard about it. Nevertheless, the general perceptions of women, men and youth are that there is visible change in the KP police, and they are relatively better than before. Actually, due to the fact that they were targeted during the conflict and suffered high loss of life, the police got the sympathy and support of the public. This unusual show of support caused police to change their attitude toward the community, and overall police-community relations improved. Also, since militants were sometimes from within the community, the police tried to keep a good liaison with the community and make them partners in favor of peace and against insecurity. However, particularly the male respondents from the selected villages believe that much more is needed to change the attitude of key officials within the police stations who register First Investigation Reports (FIRs) and undertake investigation of the cases. For them, who are usually the ones reporting crimes, police officials still use delaying tactics, favoritism and inclination towards supporting the powerful party. The level of trust of the community in the police is still quite low when it comes to murders and other sensitive cases, particularly when the case is between an influential and a poor family. The same respondents, however, found and appreciated what they described as the modest and excellent attitude of police officials and personal who are at checkpoints, out in traffic, and elsewhere outside the police stations. This shows that more work is needed on police personnel who work in police stations and deal with the registration and investigation of crime. The women police stations or women desks are unfortunately still not active in many police stations. The women respondents raised the issue of confronting men if they visit police stations. Police officials and even the public still assume that it is a man's job to even report womenrelated issues. This attitude reduces the chances for women survivors/victims to report violence or other abuse cases, particularly against male family members if such a case arises.

Police officials praised the new Act, as it empowers and depoliticizes them. Police officials and personnel support the fact there is little or no political intervention in their affairs; this is what the new Act is promoting. The Act lays down a new command and control system and police officials felt this government is facilitating the police department in bringing the required changes to their structure. It was actually the political will that resulted in the passing of the police act, and it is hoped that this political will continues at least as long as the same party that passed the Act is in power in KP. However, police as a real independent institution that can stay independent irrespective of changes in the government or their influence has yet to be established. On the reforms, several community members and police officials pointed out that de-politicization and the new Act do not necessarily lead to improve police-community relations. They insist that police need new training and the will to learn and practice a behavior of service provider rather than being a force to command and control the public. Improving community-police relations is a larger outcome and it will not be realized within a short time period. Police officials and personnel realize the challenges of implementing the 
Act and the degree of adjustment needed on the part of police to follow it. One of the police officials mentioned that there is a need to develop a comprehensive strategy and financial mechanism to reform the police and make it a service-oriented department according to the demands of the Act and expectations of the general public.

The head of one police station, while appreciating the importance of community-police relations, admits challenges remain; "Cooperation and trust between community and police is a must for peace and the law-and-order situation". The community, however, is not always supportive and helping the police in spotting and reporting unwanted incidences, criminal activities and domestic violence etc. because they prefer to avoid police and police stations. This is probably because the police are historically notorious for unnecessary investigation and it is better to keep away from them. Police need a long-term and better strategy to win the true support of the public. "Through better community-police relationship we can fight terrorism, crimes and improve peace and security" said the in-charge of a police station. To emphasize their will to serve the public, a police investigation officer claimed that "We are not taking political or other pressure in filing FIRs and doing investigations". He also emphasized that having a separate investigation section in police station improved their performance. Nevertheless, community members still see a need for further improvement in FIR, investigation and interrogation processes. Police in general however, focus more on operations than on investigations. Operations often create panic and mistrust in the community against the police, while fair investigations build trust of the public in the police. This imbalance of operation and investigation can be seen from the fact that around 34000 police personnel are in operations and only 3790 in investigation. Similarly, the Senior Superintendent of Police (SSP) Operations has over 6000 under his command, while the SSP Investigations has only 238 staff. Comparing this with the cases of crimes, one investigator would have to deal with an average of 75 major cases/year. A police officer in Peshawar explained that this affects the quality of investigations, as one person should only investigate an average of 25 cases per year.

The majority of the male respondents believe that mere legislation in the form of an Act and de-politicization of police is not enough. They showed concern that although de-politicization would empower police, more powerful police with the same attitude could make the police stronger in their misuse of power. Therefore, they ask for the development of police as an institution with a proper check-andbalance system and service-oriented training. On many issues, women's perceptions of the police are likely influenced by what they hear from their male family members, as it is not common for women to directly interact with the police and police station. Nevertheless, all of the women respondents say they always avoid the police and police station unless there is an extreme emergency e.g. genderbased violence against their own family members where they have no other option. A widow from Swat narrating her story mentioned that "to approach the police station you still need the support of an influential Khan, otherwise it is very difficult for your case to be investigated on the basis of merit". Another woman in Peshawar explained that women are always accompanied by men whenever there is a need to go to the police station.

Apart from this gendered asymmetry, the picture is one of a police force that is improving, both in the eyes of the male community and the police themselves. In Swat, a young Sikh man was happy with the police performance even before the reform process. He explained, "Our community does not face fear or unwanted threats from the police. Our police were very friendly from before; however, they are much better after the Swat conflict" [22]. One of the respondents from a village in Peshawar said that "one can now observe a positive change in police stations across KP. The attitude of police has drastically changed, and they consider the community as partners for maintaining law and order situations". A policeman in Peshawar explained that "we share with community leaders our expectations and build trust through joint planning for maintaining law and order in the area". A police officer from Swat was satisfied with the Police Act saying that "it will bring transparency and accountability into policing. The efficiency of police will be improved which will be helpful in improving policecommunity relations. It will truly make police a servant of the community". He further said that the KP Police Act is a true manifestation of the idea of COP because many of its sections serve the COP philosophy. For example, complaint cells are established comprised of members of local governments, civil society and community members, and the District Police Officer (DPO) is bound to present a semi-annual report to the local government. A police officer from Peshawar expressed that "The KP Police Act aims at empowering community members in terms of holding police accountable for misuse of their authority. This is contrary to the police order 2002, when police were made accountable to the bureaucrats and politicians". According to this police officer, the Act has also empowered the executive structure of KP Police as the Inspector General of Police (IGP) has been made an ex-officio secretary with total operational, administrative and financial autonomy. Earlier, the Provincial Public Safety Commission could recommend the IGP's transfer and posting to the government, but now it does not have this power. Another middle-ranking police official said that "the new Police Act has empowered police by depoliticizing the institution. In the past, the police was highly politicized. Politicians used to easily influence the transfer and posting of Station House Officers (SHOs) and other police personnel to fulfill their own political goals and personal interests. They would just need to call the Senior Superintendent of Police (SSP) for the transfer or posting of police employees. The new Police Act has now empowered the Deputy Inspector General (DIG) for the transfer and posting of police officers and can't be influenced by a politician so easily. As an institution, the police can now resist external pressure". 
In terms of addressing women's needs in police reform, both police officials and communities demanded of the government to increase the quota for women police in the KP Police. The Police Act has opened for more participation of women in the police and more attention to their needs when reporting crime. It is believed that this will help in gender mainstreaming and better facilitation of complaints of women. With these changes, police officials feel it may be easier for women to file cases against men, and will not consider police stations as places only for men. Women respondents, however, have additional concerns. Even with access to female police, they did not like having a women's desk within a men's police station. They prefered a separate women's police station or complaint center outside outside the police station for better access and facilitation of women by the women police. If one look into the cases registered in police stations, they are mostly by men, including cases related to women. This is because local culture, norms and values discourage women to visit police stations. Rather than bring these issues to the attention of the police, men would either work to solve them locally, or put the issues under the carpet to protect their own honor.

Overall, police reform is considered a welcome move of the government of KP. Police already have started certain initiatives and the general public is excited about a better police in KP. When discussing the reforms, the Disputes Resolution Council (DRC) in particular was mentioned by almost all respondents as a positive step towards good service from the police department.

\subsection{Dispute Resolution Councils (DRCs)}

The police in KP took an important initiative to formalize the involvement of the local community by introducing Dispute Resolution Councils (DRCs) across the province [23]. This system of alternative dispute resolution is based on active participation of the victim, the offender and local community elders in pursuit of reconciliation by adopting a balanced approach that preserves safety and dignity of all stakeholders [16]. DRC are organized at district level and members are selected from within the local communities. DRCs were in fact first initiated in 2014 across KP province, prior to the Police Act, with the aim of resolving disputes of a petty nature. Before that, other reconciliation committees were also launched from time to time and in different divisions and districts of the province. Initially, DRCs faced problems regarding their legal status, but the KP Police Act 2017 gave legal cover to DRCs in its Chapter 6 and 73 [19]. DRCs have now been launched in all KP districts with a specific administrative structure and clear roles and responsibilities. The DRC committee is comprised of 21 members including retired civil officers, lawyers, educationists and other notable individuals from the community. Most of the committee members are men; the representation of women is quite limited. Thus, the domination of men in the police force is mirrored in the DRCs.

DRC initiatives are aimed at providing free, fair and fast justice to women and men in civil and even criminal cases. The DRC is open for disputes of any nature, when the two parties agreed to settled their cases and avoid police station and courts. DRCs have been able to make timely decisions on criminal cases which had been in the courts for years. Once reconciliation of court cases are made among parties, the decision is submitted to the courts and the case is closed on the consensus of the parties.

DRC records in Peshawar and Swat as well as data from the community interviews clearly indicate that community members prefer to bring their disputes to DRCs-and the police encourage them. The procedure to process any dispute in the DRC is considered simple and it is free of cost. For example, the victim writes an application to the relevant police officer requesting to take notice of his/her complaint and refer it the local DRC. The application incurs no fee. The application is forwarded to the DRC, who then examines the application and summons both the victim and the offender. The committee listens to both parties, and then starts negotiating and resolving the conflict. Depending on the nature of the conflict, some cases can be resolved on the same day and others might take weeks, but only a small fraction would go beyond a month. After conducting several meetings between the parties, there comes a point when both parties agree to the decision of the committee. Three members of the DRC form a jury to hear a case, so there is a total of 7 juries that deal with cases in any one week. Every day any one jury is hearing the cases in the DRCs designated office. Every member is bound to be a part of a jury. Both parties most often accept the decision and the issue is resolved forever. This is very different from cases where an FIR is registered, and the case goes to court, which can take years to make a decision, and which may not necessarily resolve the dispute and the opponent party has the option of appeal to higher courts. While DRCs are seen to be effective for petty offences, both police and community conveyed that DRCs can in some ways encourage crimes, as both criminals and influential know they can bargain heavily to get rid of harsh penalties, such as life in prison and a death penalty, punishments that might be forthcoming in formal courts.

One DRC member in Swat summarizes the working mechanism of DRC saying that, "When conflicting parties approach us, we give them three options for resolving their dispute. They can choose either Sharia (based on governance from Quranic scripture), government law and/or Pashtunwali (Pashtun's code of conduct or local traditional laws). The majority of the cases coming to DRC include domestic violence, husband-wife issues over the custody of children, money, debts, land and property issues, robbery, murders etc.". The DRC members and community men and women respondents admitted that honor-killing, dowry disputes and other cases where women are victims are also happening in the areas from time to time but are often not reported to police or DRCs. In such cases aggrieved women might not get the required justice, but the family men and women prefer to put things under the carpet 
and avoid public discussion about these women and thus save their own honor. Here one can see that community women and police women share a common experience of discrimination. Nevertheless, the DRCs records show that women do approach DRCs, and women respondents confirmed that they feel more comfortable sharing their issues with local leaderships in DRCs as compared to police stations. The DRC respondent explained that DRC members consider themselves as more sympathetic to women, and claim they try to resolve their issues on priority with a slight inclination towards women as they rely more on locals norms and values rather than government rules and regulations. Once a $\mathrm{DRC}$ formally hears from both parties, the committee takes time to deliberate the matter in detail and under the spheres of the legal system chosen by the parties. The case is often resolved in a series of separate and combined meetings with the parties. In Swat, they serve randomly across three police stations. Responding to a question if the DRC members need any capacity building or training from the government, the respondent was of the view that they are Pashtuns and they know their traditions and customs on how to resolve disputes better than anyone. On the question of expertise, it was explained that in the committee they have legal, Sharia, educational and local experts with long-term experience in their respective fields. They don't feel the need of any training from the government; rather they demand a well-equipped office with computers, printers and internet facilities so that they can speed up their work in a more professional way.

Another respondent from a DRC committee said that "the DRC aims at providing a forum for the conflicting parties to meet and listen to each other's' grievances and have informal interaction in the presence of a third party. This reconciliation approach is quite effective in resolving disputes and eliminating grievances among conflicting parties through interaction and mutual understanding. Courts cannot provide such a forum and environment. In the courts, a long-awaited decision where a lot of time and money have been used, does not necessarily settle the enmity.". Another DRC member opined, "Once people come to the DRC they motivate others to resolve disputes through the DRC as here they get speedy and free-of-cost resolution to their petty disputes. If the government provides strong legal cover, necessary resources and attention to DRC then it will lift more than half of the burden from judiciary, courts and police administrative offices".

The majority of the male respondents from the community, including the aggrieved parties, were also satisfied with DRC. Through the DRC, local communities can avoid 'Thana Culture', unwanted contact with the police, lengthy and costly court procedures and disputed decisions. This fact was endorsed by the DRC progress report between the years 2014-2017 from the police station in Peshawar. During this period, 2521 cases were brought to the DRC by community members where 2372 were successfully resolved and 149 are still pending. The remaining cases were referred to courts for further action. The data from the police station in Swat shows that more than 2000 disputes were resolved successfully during 2014-2017. Some of those cases had been in the courts for more than 25 years but the DRC resolved them in just a few months. The majority of male respondents claimed that DRCs resolve public disputes faster than the regular courts in Swat, and that the methods applied in the case proceedings are very convincing and flexible. The progress reports of other DRCs are equally encouraging and political leaders, police department and the general public often quote those figures while advocating the role of DRCs in KP.

Female respondents, however, see DRCs differently. Most of the female respondents argue that women's representation in DRCs is not only less but almost non-existent. Knowing the composition of DRC, they mentioned that there is only one woman out of 21 members of the DRC in the police station in Swat, and none in the police station in Peshawar. For them, DRCs are for men, where they discuss and decide men and women's disputes. Another female respondent blamed cultural barriers that stop women from participating in DRC proceedings. The same female respondents narrated that most of the cases brought to DRCs are related to domestic issues, land grabbing, inheritance and land demarcation. Domestic violence, honor killing, and women's rights related issues do not come to DRCs in order to save men's honor. One female respondent from a civil society organization said, "Women affected by domestic violence and other conflicts are hesitant to visit police stations or DRCs because the society in KP province is too conservative and male-dominated. Women think of police stations and DRCs as places meant to deal with criminals where men manage all the affairs. We need separate women's police stations that could handle our issues".

Other female respondents were of the view that "even educated women with a complaint would think many times before visiting the DRC office in a police station due to the prevailing stereotyped perception of the police and justice culture in Pakistan". They explained that many women do have many complaints, but they do not have women-only forum for debate and decision-making.

Nevertheless, women respondents prefered to go DRCs instead of a police station.For them DRCs, though maledominated, are still much better than police stations, as they consist of mostly elders, educated and local people with good reputation. Therefore, a number of female survivors/victims of domestic violence nevertheless chose to put forward cases to the DRC against their family members (e.g. husband, brother-in-laws and brothers etc). Most of the cases raised by women, however, involved inheritance or custody issues. For example, a divorced women in $\mathrm{Pe}$ shawar appreciated the role of DRC where they granted her custody of her child and monthly cash support from her ex-husband.

While DRCs are considered a better option that having direct contact with the police, both male and female respondants expressed that there is much room for improvement. Women respondents want a higher women's quota in DRC 
and a separate panel of women to address only women's issues. Also, better technical and official support to DRC members could further expedite their performance. DRC members work as volunteers, and some respondents were of the opinion that better recognition of the services of the DRCs members from the government would convey a better image of the newly established institution. Some of the respondents said that $D R C$ is a modern form of Sharia and jirga (council of elders for resolving disputes, a prominent pillar of Pashtunwali-code of conduct of the Pashtun), both of which encourage communities to resolve their disputes through reconciliation. The main difference between a jirga and DRC is that in a jirga the conflicting parties give consent to the members that whatever decision is announced, they will accept it unconditionally, but in DRC the conflicting parties can challenge the decision and can transfer the case to the courts for further proceedings if they so choose. Therefore, DRCs are somewhat less binding compared to jirga, and parties that feel they were not treated fairly by the DRC can consult the regular court system.

\subsection{Technical Reform Initiatives in Police}

For improving community-police relationships, the KP Police has launched a number of ICT initiatives. These initiatives provide communities with easier access to police and police stations and provide new ways for community voices to be heard. In September 2015, the KP Police established a Police School of Information Technology, where police are trained in the use of ICTs in policing. Gaining access to the police was quite a difficult task for community members in the past, but KP Police has come up with several ICTs which provide swift police response to the general public in order to win their trust by enhancing police accessibility. For example, community members can lodge an online FIR and register complaints. The Victim Services Toll Free Number provides telephone access to victims who need quick service or are not in a position to visit a Police Station to file a complaint. Using the toll-free number, a victim can complain about a police officer and police stations. The service aims at both reducing police response time and providing the Provincial Police Office with a monitoring tool for assessing the speed and quality of police service. The Police IT School initiated several other digital systems as well, including a criminal record verification system (CRVS), identity verification system (IVS), vehicle verification system (VVS), one click SOS alert service for educational and other vulnerable institutions, geo-tagging of crime scenes and hot-spot policing [24]. To manage the use of ICTs the police department has established a Police Access Services Center (PAS) in the Central Police Office in Peshawar. Community members can now access police by sending an SMS, and the receiving police officer is bound to respond to the complaint within 24 hours. Citizens can attach geo-tagged multimedia content, such as photo, audio, or video to support the complaint and ensure prompt action. They can also contact the police by fax, email, the toll-free number, by visiting the police website or by visiting the Police Access Service Center in the Central Police Office. Moreover, KP Police has established Police Access Lines (PAL) in each district headquarter. PAL is functioning as a one-window assistance offered to the community members for the resolution of their issues and disputes.

Both the police and the communities have expressed that the ICT-based initiatives of KP policehave helped in establishing good relationships between the police and local communities. A community leader in Swat explained that "the ICTs initiatives have enabled community members to lodge online First Information Report (FIR) without visiting the police station in person. The FIR automatically is stored in the Central Police Office database. The police are bound to respond in the next 24 hours to the FIR and contact the complainant. If the chief of any institution is sincere and committed, then the whole system gets on the right track, the same is the case with KP Police because the police institution now has a sincere and committed chief with all relevant power in hand".

Another respondent from Peshawar narrated that "community members have started respecting the local police due to better interaction between police and community. The use of ICT by the police enables the general public to contact police anytime through a toll free number and SMS without visiting the police station". The police are also positive to these initiatives. For example, a policeman from Peshawar explained that "Modern ICT initiatives in policing have revolutionized KP Police and the nature of our work. The capacity of police has been enhanced by establishing various ICT trainings being conducted for police officers and low-ranked personnel in the School of Information Technology in Central Police Office Peshawar".

Recently, KP traffic police have been equipped with body cameras. These cameras influenced the traffic police to act politely and responsibly when dealing with the public since they are often accused of taking bribes and being harsh with the public. Other government departments are following suit. The Local Government, Elections and Rural Development Department has, for example, initiated online provision of social services where one can apply for birth/death/marriage/nikkah (engagement) certificates, request to get information and register public grievances against various government departments including police. These kinds of initiatives have brought the police and communities closer, and both the police and the public believe ICT initiatives can reduce the chances of corruption in the police and the ill treatment of the public.

One of our female respondents from the police, however, was not aware of the use and availability of the latest ICT tools in policing, despite the fact that KP Police has incorporated numerous ICTs in its policing system. This could indicate that there is a need for a particular focus on the training of women police in these technologies. Another respondent from the police department explained that the ICTsareused by both men and women, as they are getting phone calls and SMSs from both genders. The earlier 
trend of only men being visibile in disputes and visiting police stations is thus changing, as women can also register complaints and FIRs online on their own. This makes the importance of policewomen having skills in ICT use even clearer, as they can more easily follow-up on calls from women citizens.

Another policeman expressed his views by saying that use of ICTs not only improves communication between police and community but can also enhance communication within various security agencies, and enable communication during conflict or emergencies through cellular phones, radio stations (news/alerts/warnings broadcast from security forces) and help lines. ICTs, however, can also be used for crime and inducing conflict, as was the case in Swat when the militants used FM radio to communicate their messages and gain the support of the public. ICTs can also be misused by the police in the event they are not properly held accountable to the public. It is therefore imperative that the police are both competent in ICTs, but that they also remain under the auspices of public control bodies. Also, the ICT initiatives are relatively less useful to (a) the majority of rural inhabitants, (b) women and (c) less educated women and men. Although people in these segements of society comprise the majority in KP, they often do not have access to internet, cell phones or technical competence, and they are therefore not able to use such services. Therefore, inclusive ICT initiatives for the above three groups of society is needed.This might include special complaint centers, training, and focused assistance from activist groups and ICT experts.

Despite taking all of these initiatives to improve relations between the police and the communities, the KP Police chooses not to call them community-oriented policing. For some police officials, community policing is a foreign/donor funded approach, despite it being anchored in national policing policy. They claim they have been practicing community policing for many years without naming it as such. For example, the police department informed that local police and community members established Local Peace Committees (LPCs) and Community Policing Forums (CPFs) in militancy-affected districts across KP. The LPC initiatives made significant contributions towards maintaining peace in militancy-affected districts of KP province [25]. LPCs bridge the gap between local community and state authorities by providing information, identifying miscreants, and reporting subversive activities in neighborhoods. In the recent past, LPCs have proved effective for providing social justice and elimination of militancy in the affected areas of KP. While this collaboration was initially focused on informing on militants and negotiating peace, it has nevertheless formed the basis of trust between the police and communities which can now move forward to other human security issues as exemplified by the preventative aspects of the PLCs and the dialogic nature of the DRCs.

In addition to being better able to address the needs of the communities, it is anticipated that the police reforms will contribute to reducing the workload on police stations and on the courts as well. The PLCs are relatively new, but there will soon be a lot to learn from their experiences. The DRCs are already working in KP, and other provinces are working to establish similar bodies. Lahore High Court, for example, has already set up a bench for dispute resolution and out-of-court settlement. Alternative dispute resolution is also debated in parliament and they appreciate the reforms. However, there is a need to refine the DRC processes and for quick and just services and to ensure justice, peace and human security without compromising the rights of women and men.

\section{Conclusions}

In post crises Pakistan, the role of police has changed and broadened from conventional policing to fighting terrorism, peacebuilding and gaining the trust of the community. In KP, police play a central role in establishing a sense of security and stability in the lives of people living in a post-conflict situation. After decades of neglect, the government is now investing in the ability of the KP police to enable this. On the one hand, the KP Police for the first time is working closely with other security agencies countering terrorism in joint operations. The police received new training from Army, and the government equipped them with high-tech weapons and ammunition to be able to safely meet the challenges of a conflict-ridden region. At the same time, the police are shifting from a force to a more democratic institution. The police reform initiatives of the government of KP seem to be on the right track so that the police can meet the expectations of the public and work for both peace and human security. With this new reform agenda, visible change in the KP police is being observed by diverse groups of stakeholders from the community to police officials.

Equally important as police reform is a mature response and support from the community. Our findings show that the majority of the respondents were of the view that these technical, political and institutional initiatives have paved the way for policing where both the community members and police force work together as partners for problem solving and building peace in the conflict affected regions of KP. Nevertheless, there remain many issues on the part of community that make cooperation a challenge, including high illiteracy rates, high crimes rates, gender-based violence, and a pluralistic society having a history of mistrust of the police. Unless communities are ready and able to cooperate and support police in peace building and human security, most the reform initiatives might not be productive. Therefore, working with communities to build trust and a sense of responsibility and understanding of their role in working towards a common goal of peace is important. This can be done through awareness campaigns, and engaging communities and civil society organizations to make them part of the solution of their security issues.

Policing in KP has historically been challenging, as the Pakhtun do not easily accept outside authority and react to any misbehavior by the government authorities in particular. 
The police know that any un-polite attitude with locals can lead to conflict between police and community or with an individual. Police staff at the police station level is aware that any misbehavior with even a criminal can put their life in danger. Therefore, even if they are not cooperative, police in $\mathrm{KP}$ are historically not seen as arrogant and use force quite carefully, in contrast to the perceptions of police in the other provinces. KP police is therefore generally known as being respectful and polite. Given this legacy of the KP police, and their proactive process of reforms, the current government trusts the motives of the police and avoids unnecessary interference in their affairs, supporting them when needed. The above-mentioned political, institutional and technical initiatives are aimed to further strengthen the police department and to make them pro-community and service-oriented. We see from our study that the majority of the respondents were of the view that strong political will and institutional support will shoulder the above-mentioned initiatives in KP.

Police reform is widely debated, argued over and desired in Pakistan, with a clear focus on making the police both service-oriented and pro-community. This has resulted in legal, institutional and technical reforms in police such as the Police Act 2017, the PLCs, DRCs, and ICT-based initiatives. These interventions are for the most part welcomed both by the police and the public. Better-equipped police can respond quickly and politely. Police feel more freedom and take more responsibility due to the new Act and ICT-based initiatives. The public feels more ownership and responsibility when they are engaged in PLCs and DRCs and the roles provided to them in the new Act. ICTs enable the public to approach police quickly without taking the trouble of visiting police stations and facing harsh questions. There is less political intervention and the police department is relatively freer to make decisions. However, it is not always true that all decisions of the police are merit-based and pro-community, and issues of women's representation and security remain a serious challenge in implementing reforms. Changes in behavior and attitude are critical, and must be an important part of regular police training and educational programs. This is a long-term process, however; the police and the government need continuous reforms, as well as the support of the communities.

On a more fundamental level, while the police may in principle and practice work on a wide range of human security issues, what constitutes insecurity in society is quite contentious. Police, other law enforcement forces, security forces and community women and men have different understandings, perceptions and information on threats to human security, leading to different strategies on how to achieve it. Due to the sensitivity of security issues in the region, there is little debate between community, police and other law enforcement forces on what human security might mean. Therefore, action taken by police or law enforcement forces which is not well-understood by the public can easily create mistrust and decreased support of the government. Therefore, there is a critical need for better communication and the forging of partnerships between the community and the police such that they can work together towards a common goal of peace. To this, the police reforms of KP are thus far a promising contribution.

\section{References and Notes}

[1] Mehboob S. Governance and Militancy in Pakistan's Khyber Pakhtunkhwa Province; 2011.

[2] Awan I. Policing Pakistani Style in the Theatre of Terror. Asian Journal of Criminology. 2013;8(3):191-206. doi:10.1007/s11417-013-9166-2.

[3] Abbas H. Reforming Pakistan's Police and Law Enforcement Infrastructure. Washington, DC, USA: US Institute of Peace; 2011. Available from: https://www.usip.org/publications/2011/02/reformingpakistans-police-and-law-enforcement-infrastructure.

[4] Rohde D. Threats and Responses: Law Enforcement; Pakistan's Police Force Struggles to Find the Resources It Needs to Combat Terrorism. New York Times. 2002;Available from: https://www.nytimes.com/2002/09/30/world/threatsresponses-law-enforcement-pakistan-s-police-force-strugglesfind.html?rref=collection\%2Fbyline\%2Fdavid-rohde\&action= click\&contentCollection=undefined \&region=stream\&module $=$ stream_unit\&version=search\&contentPlacement=1\&pgtype= collection.

[5] Abbas H. Stabilizing Pakistan through Police Reform. New York, NY, USA: Asia Society Washington; 2012. Available from: https: //asiasociety.org/files/pdf/as_pakistan_police_reform.pdf.

[6] Abbas H. Police \& law enforcement reform in Pakistan: Crucial for counterinsurgency and counterterrorism success. Cambridge, MA, USA: Institute for Social Policy and Understanding, Belfer Center, Harvard Kennedy School; 2009. Available from: https://www.belfercenter.org/publication/police-law-enforcementreform-pakistan-crucial-counterinsurgency-and-counterterrorism.
[7] Jaffrelot C. Pakistan at the Crossroads: Domestic Dynamics and External Pressures. New York, NY, USA: Columbia University Press; 2016.

[8] Mehta S. Feudal Forces, Democratic Nations: Police Accountability in Commonwealth South Asia. London, UK: CHRI; 2007.

[9] Weatheritt M. Innovations in policing. Abingdon, UK: Taylor \& Francis; 1986.

[10] Denney L, Jenkins S. Securing communities: The what and the how of community policing. London, UK: Overseas Development Institute; 2013. Available from: http://www.odi.org/sites/odi.org.uk/files/odiassets/publicationsopinion-files/8491.pdf.

[11] Ras J. Policing the northwest frontier Province of Pakistan: practical remarks from a South African perspective. Pakistan Journal of Criminology. 2010;2(1):107-122. Available from: http://www.pjcriminology. com/wp-content/uploads/2019/01/7-18.pdf.

[12] Groenewald H, Peake G. Police Reform through Community-Based Policing. New York, NY, USA: International Peace Academy and Saferworld; 2004.

[13] Brown LP. Community policing: A practical guide for police officials. Washington, DC, USA: US Department of Justice, Office of Justice Programs, National Institute of Justice; 1989. Available from: https://www.ncjrs.gov/pdffiles1/nij/118001.pdf.

[14] Haider H. Community-based Approaches to Peacebuilding in Conflict-affected and Fragile Contexts. 2009;Available from: http: //www.gsdrc.org/docs/open/EIRS8.pdf.

[15] Eck JE, Rosenbaum D. In: Rosenbaum D, editor. The new police order: Effectiveness, equity, and efficiency in community policing SAGE; 1994. pp. 3-23. doi:10.4135/9781483327006.n1. 
[16] Strategical initiatives and institutional reforms in Khyber Pakhttukhwa Police 2015-16. Peshawar, Khyber Pakhtunkhwa, Pakistan: Central Police Office Peshawar; 2017. Available from: http://kppolice.gov.pk/ thebook/book.pdf.

[17] Bacha AH. KP Police gets $R S 2,600$ pay raise across the board. Dawn. 2014 March 18;Available from: https://www.dawn.com/news/ 1093931.

[18] ;. KP Government notification no. SO(FR)FD?7-8/2015-16/CPO/3305 dated January 3, 2018.

[19] The Khyber Pakhtunkhwa Police Act no. II; 2017. Available from: http://kppolice.gov.pk/act2017/PoliceAct.pdf.

[20] Fafen Legislation Tracker. Peshawar, Khyber Pakhtunkhwa, Pakistan: Provincial Assembly of Khyber Pakhtunkhwa; 2017. Available from: http://fafen.org/wp-content/uploads/2017/02/KP-LegislativeTracker-2017.pdf.

[21] Khyber Pakhtunkhwa Police;. Available from: http://kppolice.gov.pk/.

[22] Militants swept into and get control of Swat (the northern part of KP) in 2007 killing more than 2000 innocent people. Later on the army started operation against militants to restore the law and order situation and get control over the area after killing and pushing militants from Swat. Around 2.5 million locals were displaced and resettled in the operation;

[23] Dispute Resolution Councils. Khyber Pakhtunkhwa Police; 2014 Available from: http://kppolice.gov.pk/drc/.

[24] Reforms Initiatives in Khyber Pakhtunkhwa. Peshawar, Khyber Pakhtunkhwa, Pakistan; 2014. Available from: http://lgkp.gov.pk/wpcontent/uploads/2014/03/Reforms-Implementation-Cell-KPReport.pdf.

[25] Ahmad N, Ullah F, Asad AZ, Shah S. Local Peace Committees: Potentials Contributing Factors in the Peace-building Process in ConflictAffected Areas of Pakistan A Case Study of Maidan,(Lower Dir) in the Province Khyber Pakhtunkhwa. Pakistan Journal of Criminology. 2013;5(2):103 